Article

\title{
Retirement Expectations in Germany-Towards Rising Social Inequality?
}

\author{
Moritz Hess \\ Institute of Gerontology, Technical University Dortmund, 44339 Dortmund, Germany; \\ mhess@post.tu-dortmund.de
}

Received: 1 May 2018; Accepted: 9 July 2018; Published: 10 July 2018

\begin{abstract}
In the last 20 years, German policy makers have reformed the pension system and the labor market with the aim of prolonging working life. As a consequence, older workers' employment rate and average retirement age rose. In addition to the actual behavior of today's retiree cohorts, the reforms also influence the expected retirement age of future pensioners, the development of which will be investigated in this paper, arguing that they have adapted to the reforms and increased their expected retirement age. The analyses are based on data from the SOEP and DEAS survey and results show an increase of the expected retirement age. However, while high-skilled workers both want and expect to retire late, low-skilled workers prefer to retire early but expect that they have to work longer in order to ensure a reasonable pension. This finding hints at rising social inequality in the transition from work to retirement.
\end{abstract}

Keywords: retirement; Germany; social inequality; expected retirement age; ageing; pension policy; SOEP; DEAS

\section{Introduction}

In Europe, the aging of societies is challenging the sustainability of pension systems, and reforms aiming at an increase of the average retirement age have been implemented in most European countries. Future pensioners will have to adjust to these changes of the institutional contexts in which they will make their retirement transitions. Taking Germany as an example, in this paper I will examine whether future pensioners have adapted to the reforms of the pension systems by answering the following research questions: Have they increased their expected retirement age? Does this potential increase vary between different social groups? Moreover, do these differences between groups hint at the (re-)emergence of social inequality in the retirement process? The German case is well suited to study these questions. With decreasing fertility rates and increasing life expectancy, Germany is one of the fastest aging countries in the world, and predictions show that the share of people aged 65 and older will increase from 21 percent in 2010 to 28 percent in 2030 [1]. The welfare state's financial sustainability is under pressure due to a growing number of beneficiaries and less contributors, and in particular, the public pension system is expected to face severe economic problems [2-6]. In reaction, German policy makers have introduced several far-reaching reforms with the aim of increasing the retirement age and, thus, relieve the pension system of financial pressure: They lifted the statutory retirement age from 65 to 67 [7], introduced training programs for older workers [8], and abolished early retirement pathways $[9,10]$. Consequently, the average retirement age and the employment rate of older workers began to rise [11,12]. However, it is important to study not only the actual behavior of the current pensioners but also future retirees' opinions about their retirement timing, as expectations and plans when to retire have proven to be a good proxy for actual retirement behavior [13-15]. This is crucial for the long-term sustainability of the German pension system. Future pensioner cohorts have to agree with the reform, increase their expected prospective retirement age, and accept that they will 
retire later than their predecessors. Previous literature has shown that the expected retirement age has indeed risen after pension system reforms, for example in Sweden [16] and the Netherlands [17].

I will go beyond these studies by including a longer observational period of almost 20 years into my analysis. Earlier work researched the development of the expected retirement age mostly over a time span of 10 years. In this study, data from the mid-1980s to the late 2000s are used in order to test whether the trend of increasing the expected retirement age is a rather recent phenomenon which started only in the 2000s or if it is a longer-lasting development. In addition to investigating a longer period of time, the analysis will also examine if the increase of the expected retirement age is stable or varies across different types of older workers. Recent studies [18,19] show that especially two groups in Germany continue working past the statutory retirement age: employees with high education, because they often have a high identification with their job, and employees with low education, because they are under financial pressure.

This paper will investigate whether a similar trend can be found for the expected retirement age as well. To summarize, the first aim of this paper is to investigate how future pensioners have adapted their expectations concerning their retirement timing to the reforms. The paper's second aim is to explore how these adaptations towards the reforms vary between social groups. I argue that, with the closing of the early retirement pathways, in particular, low-educated and low-skilled workers feel the financial pressure to delay their retirement in order to receive a sufficient pension to maintain their standard of living and with the same replacement rate as their predecessors in previous years when retiring early. Therefore, they have increased their expected retirement age faster than better-educated workers. This indicates a potential emergence of social inequality in the choice of retirement timing, which has already been pointed out in previous German studies [19,20]. It seems as if the choice when to retire is becoming a privilege only those with high pension claims can afford. Hofäcker and Naumann comment [18: 478]: "[ . . ] the repercussions of institutional reform may not be unanimously positive, indicated by a rise in social inequality in retirement decisions, suggesting that particularly lower-educated workers may not be able to meet the demands of or even benefit from activation policies". This assumption is tested by combining data from the German Socio- Economic Panel (GSOEP) and the German Aging Survey (DEAS), which allows comparing the expected retirement age in 1987, 2006, and 2008. The paper is structured in the following way: First, I will describe the reforms of the German pension system and the labor market in more detail and will derive hypotheses. Subsequently, the data set and the method of analysis are introduced and the results presented. A discussion of the findings and a delineation of potential societal implications will conclude the paper.

\subsection{The Reforms of the German Pension System}

Germany's economy, which had been rapidly growing after the Second World War, faced its first severe problems in the 1970s, when the oil crisis and growing international competition put the important production sector under pressure. In reaction to this, companies cut costs by dismissing their workers into unemployment [10]. Fearing unpopular high unemployment rates, German policy makers tried to relieve the labor market of pressure and, hence, reduce the unemployment rate [11]. In the field of pension policies, the idea of early retirement became the dominant principle. Older workers were offered financially attractive early retirement opportunities, which they willingly made use of [21]. Policy makers, companies, and trade unions alike hoped that the younger workers would fill the resulting vacancies and that the unemployment rate would consequently decrease [22]. Early retirement was possible via different routes which offered older employees generous compensation for retiring earlier than the statutory retirement age of 65 [21,23]. Men who had contributed to the public pension insurance for 35 years were enabled to retire at age 63, women even earlier, at 60 years old. The unemployment and the disability insurance provided further pathways for early retirement. Older men suffering from disability and who had contributed to the public pension system for 35 years were allowed to retire at the age of 60 [23]. The same was possible 
for older workers who had been unemployed for at least 1 year. A fourth early retirement option was the block model of the old-age part-time work scheme, which allowed workers to retire before the age of 65 with comparably small pension deductions. After the German reunification in 1990, the Old Age Transition Scheme made it possible for employees in East Germany to retire already at 55 if becoming unemployed [24]. These generous retirement options were financed by public subsidies, which were often complemented by payments from the companies. Especially large companies in the production sector pushed blue-collar workers and white-collar employees holding lower positions in the hierarchy into retirement in order to lower labor costs [21]. Older workers willingly used the opportunity to retire early with only small financial penalties and retirement before 65 was seen as the standard, while retirement at age 65, or even later, was the exception [25]. Consequently, the employment rate of older workers declined drastically [12,26], falling from 50 to 35 percent for the age group of 50 to 65 between 1970 and 1990 [27]. However, this decrease varied according to different groups of older workers: It was stronger for the low educated than for the high educated, because especially blue-collar workers and low-qualified employees in the production sector were pushed out of employment and most frequently used the early retirement options via the unemployment and disability insurance [18]. In 1990, the employment rate of male older workers with lower secondary education was at 40 percent, while it was at 60 percent for their counterparts with tertiary education.

At the end of the 1980s and at the beginning of the 1990s, German policy makers became aware of the problems caused by the policy of early retirement, which was threatening the financial sustainability of the public pension system since fewer contributors faced a growing number of beneficiaries [4]. In addition, a shortage of qualified labor in high technology industries and the health care sector became visible in the early 2000s [20]. These effects were further reinforced by the demographic aging of the German population. In response, policy makers introduced measures to delay retirement timing and prolong working life [7,8]. The first Rentenreform (pension reform) was designed in 1989 and implemented in 1992. The main modification concerned the introduction of actuarial pension reductions by 0.3 percent for every month the pensioner retired before the statutory retirement age, making early retirement financially less attractive [23,28]. In 1997 and 1998, the retirement age was raised for the early retirement pathways via the early retirement option of long-term insured as well as via the disability insurance [23], and in 2009, the subsidies for the old-age part-time work scheme were abolished [11]. In 2008, the government finally introduced a reform to raise the general official retirement age from 65 to 67 over a period from 2012 to 2031 [7]. Besides the closing of early retirement pathways and the raising of the retirement age, the German state also started subsidizing private pension insurances called Riesterrente [29] and implemented active labor market policies. Subventions, such as the Eingliederungszuschüsse ('integration subsidies') and the Entgeltsicherung ('integration vouchers'), were introduced for employers who hire older workers [11]. Furthermore, the state pays for programs-for example, the Weiterbildung Geringqualifizierter und beschäftigter ältere Arbeitnehmer im Unternehmen (WeGebAU)—which fund training costs for older low-skilled workers [30]. These programs have been quite successful at improving job stability and survival in the employment of older workers with only a little education and, hence, a larger risk of being unemployed and in vulnerable labor market positions. In combination, all of these reforms have changed the institutional contexts of retirement transition in Germany from allowing a financially attractive early retirement to promoting later retirement. The pension system and labor market reforms in Germany are regarded as very exceptional in comparison to other countries and were successful in increasing the supply of labor among older workers [27].

In addition to these institutional changes, employers also altered their opinion of older workers. Facing a shortage of skilled and qualified workers, they started to see the older workers as a potential source of experienced and trained labor [31]. This increase in the demand for labor forced the employers to implement "age-friendly" human resource measures to make older workers-and with them their experience-remain in the companies [32]. Discussions are still ongoing over the reforms' impact and whether the overall positive development of the economy and the generally rising female 
employment rates are more important than the reforms. Still, it is more than clear that older workers' employment rates and average retirement ages have started to rise in Germany [11,12]. In fact, the employment rate of workers older than 50 years has increased from 40 to 60 percent from the mid-1980s to the mid-2010s [27], and their retirement age has increased as well. Previous research has investigated further consequences of the policy shift and finds that the pension gap between high and low income workers has increased [20,21], that low skilled workers feel more financially pressure to delay retirement [18] and that a growing share of older workers has to work in addition to retirement to meet their needs [19]. This paper adds to this literature and tests how future pensioners in Germany have adapted their expectations of when to retire to the reforms of the pensions system and the labor market.

\subsection{Expected Retirement Age in Germany}

The main argument for studying the expected retirement age is that it is a reasonably precise proxy for the actual retirement timing, since older workers generally have a good knowledge of when they will retire $[13,14]$. This knowledge is based on a realistic evaluation of the pension system's rules as well as institutional and workplace contexts [33-35]. Older workers consider pension systems' and companies' regulations as well as pension deductions for early retirement on the one hand, and pensions increases for postponing retirement on the other [33-35]. Hence, expected retirement age can be seen as a proxy for future cohorts' actual retirement age. In addition, it allows a valuable evaluation of current retirement reforms that have not yet affected current pensioners to the full extent due to the time-lagged character of the pension systems reforms, for example, regarding the stepwise increase of the official retirement age in Germany. Hofäcker [33] (p. 1531) states "[ .. ] retirement plans and preferences of future retiree cohorts [ . . . ] have been affected by recent reform measures, thus allowing for a better assessment of their effectiveness." As pension system regulations are taken into account when stating the expected retirement age, a change of the institutional context like a reform of the pension system should influence the expected retirement age. Studies from the Netherlands [17], Sweden [16], the United States [36,37], and Australia [37] support this assumption, as they find an increase in the planned retirement age after reforms of the pensions system and the labor market. I expect a similar development in Germany also for the longer observational period, since the changes of the pension system cannot be attributed to one single reform but to several reforms which started in the beginning of the 1990s and lasted until the end of the 2010s, as described in the previous chapter.

Hence, the first hypothesis of this paper is:

Hypothesis 1. The average expected retirement age in Germany has increased from the mid-1980s to the mid-2000s.

Furthermore, I assume that this potential increase of the expected retirement age varies between different groups. I expect that low-skilled older employees have adapted their retirement expectations more than high-skilled workers with tertiary education, as low-skilled blue-collar workers in the production sector were the main target group of the early retirement policy [21]. They made frequent use of the possibility to retire early via the unemployment and disability insurance, and consequently, when the recent reforms in Germany closed these two pathways into retirement, they had to use alternative, financially less generous retirement options. However, in contrast to the high-skilled 'silver worker', who often occupies identity-enhancing and emotionally rewarding occupations and, therefore, retires late, low-skilled workers now feel the financial necessity of continuing to work and postpone retirement [19]. They expect that they have to work and contribute to the pension system longer in order to achieve sufficient retirement benefits. This leads to the second hypothesis:

Hypothesis 2. The potential increase of the expected retirement age is stronger for low-educated than for high-educated older workers. 


\section{Materials and Methods}

To test the hypothesis, I use two datasets: The expected retirement ages in the 1980s are derived from the SOEP (1987), and in the 1990s and 2000s from DEAS (1996 and 2008). No information on the expected retirement age is available in SOEP after 1987 and in DEAS before 1996, and as the aim was to depict the development of the expected retirement age for as long a period of time as possible, both data sets were combined. However, this combination does not affect the quality of the analysis as both are high-quality panel studies: The SOEP draws respondents from a nationally representative sample of individuals aged 16 years and older, comprising approximately 20,000 individuals which were interviewed yearly over the period under consideration [38]. The DEAS includes a nationally representative sample of 4000 respondents older than 39 years, which are interviewed every 6 years [39]. The sample used for this analysis is restricted to workers older than 49 , because at that age, retirement expectations tend to be stable within one person [40], and a realistic evaluation of the actual retirement can be made [33]. This reduction leads to sample sizes of 642 in 1987, 771 in 1996, and 1190 in 2008.

In all three datasets, a question is included that asks the respondents at which age they expected to receive their first pension. This expected retirement age is a realistic evaluation of when an individual will actually retire, taking into account the pension system's regulation, the institutional and workplace context, and potential pension deductions as a consequence of early retirement $[34,35]$. In line with previous studies that research social difference in the retirement process [18,41], education serves here as the main independent variable to measure the respondents' skill level. Hofäcker and Naumann comment ([18], p. 476): "Particularly education seems to be a valid proxy to summarize several interrelated characteristics that are known to be influential individual-level determinants of the retirement decision (e.g., work place characteristics and work autonomy, health, income, labor market chances)". I distinguish three educational levels: lower secondary degree or less (ISECD 0,1\&2-low), upper secondary or higher vocational education (ISCED 3\&4-medium), and tertiary education (ISCED 5\&6-high). Gender and marital status (in relationship and not in relationship) are included in the analysis as control variables. In addition, the respondent's occupational position (blue-collar, white-collar, public servant and self-employed) and whether the respondent has an occupational pension (yes or no) are accounted for. Standard linear regressions with robust standard errors investigate the influence of education on the expected retirement age. The following regression equation is used:

$$
\begin{aligned}
& \text { expectedretirementage }_{i t} \\
& \qquad \begin{array}{l}
=\alpha_{0}+\beta_{1} \cdot \text { education }_{i t}+\beta_{2} \cdot \text { gender }_{i t}+\beta_{3} \cdot \text { martialstatus }_{i t}+\beta_{4} \\
\cdot \text { occupationalstatus }_{i t}+\beta_{5} \cdot \text { ccupationalpension }_{i t}
\end{array}
\end{aligned}
$$

As robustness check, a Heckman correction to control for potential biases in the sample composition [42] was implemented. It is realistic to assume that the respondents who are still employed at an older age differ systematically from those already in retirement: They are better educated, have a higher employability and are more often male [43]. This systematic selection into employment-and, hence, the possibility of stating a preferred retirement age-might bias the results of the analysis, which is controlled for by the Heckman test.

\section{Results}

Figure 1 illustrates how the expected retirement age has developed in Germany from 1987 until 2008 for the three levels of education. In these 19 years, it has risen considerably across all groups of education; the average retirement age for all educational groups has increased from 60.77 over 61.51 to 63.48 years, supporting the first hypothesis of a rising expected retirement age. The finding that the highest expected retirement age can be observed for the high educated is in line with previous studies [44]. Having favorable working conditions, a higher job identification, and better means to remain longer in the labor market, they expect to retire later than the lower educated. Yet, of more 
interest for this study are the other two groups: In 1987, the expected retirement age of the low educated was lowest in comparison, and while it was approaching that of the middle educated in 1996, it was even higher than that in 2008. At least from a bi-variate perspective it seems as if the relation between education and expected retirement age has changed from a linear to a u-shaped one.

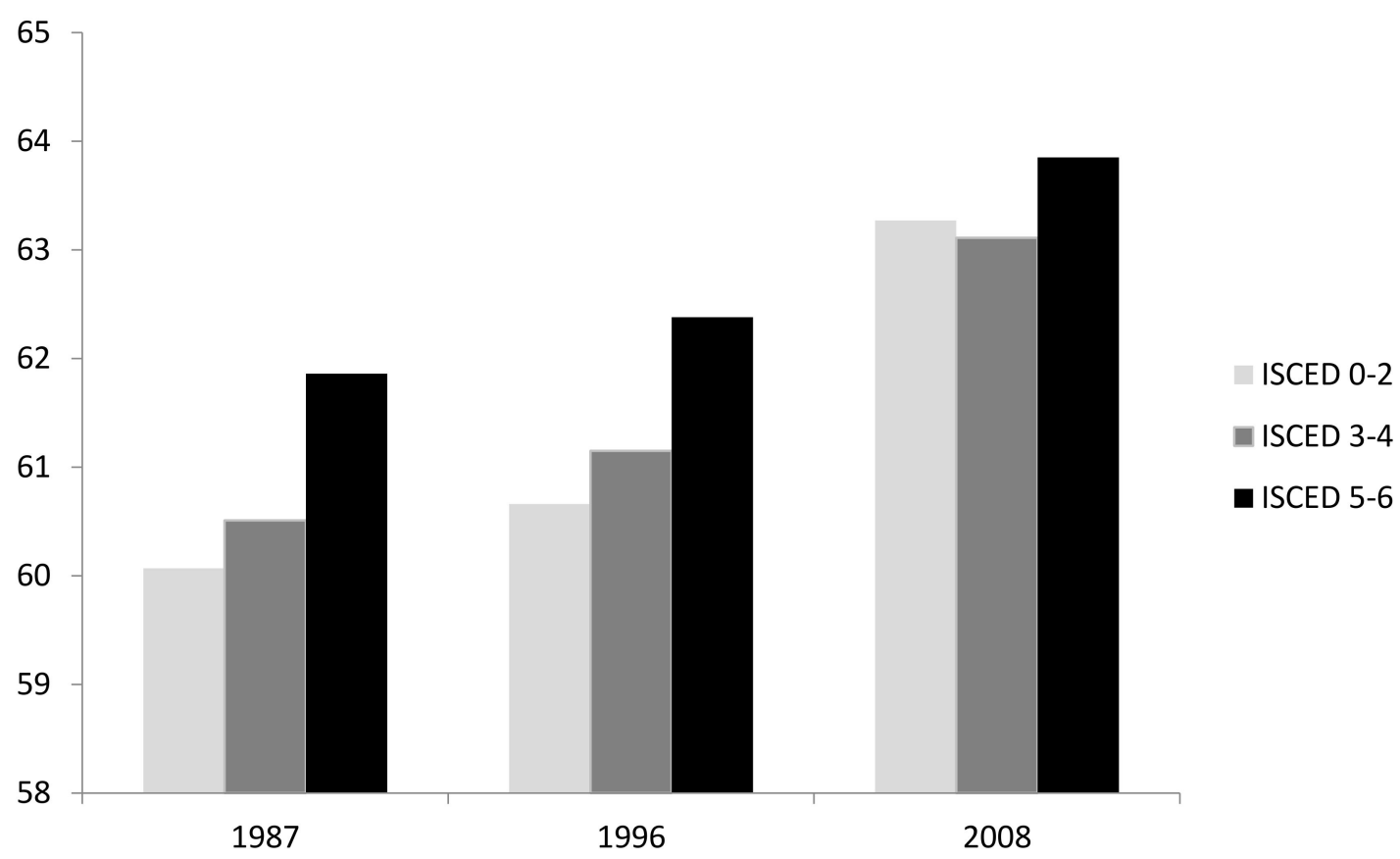

Figure 1. The Development of the Expected Retirement Age by Educational Group.

The descriptive results are supported by those of the multivariate analysis. Table 1 shows the results of a linear regression of education and the mentioned control variables on the expected retirement age in the 3 years of observation. The control variables' effects reflect those found in earlier studies. Women and individuals with a partner expect to retire later than men and those without a partner [45]. The rather low expected retirement age of women can be partly explained by the traditional male-breadwinner model-meaning that only the husband is working, while the wife does mainly housework and cares for the children - that was encouraged by the German welfare state for years [12]. And although reforms are now aiming at increasing the female labor market participation rate, women still work much less than men and have lower incomes as well as retire early and, thus, have much lower pensions. This is the main reason for the significant gender difference in the expected retirement age. Self-employed people are also expected to work longer. Due to occupational selection, self-employed people are often intrinsically motivated concerning their work and, hence, have a preference for a longer work life [46]. The results for education-the main explanatory variable of this analysis-support Hypothesis 2, which assumes that the increase of the expected retirement age was stronger for the low educated. As depicted in Figure 2, a linear connection between education and expected retirement age can be observed in the 1980s. This linear relationship shifts into a rather u-shaped one, as in 1996 older workers with medium education already expect to retire earlier than those with low education, and this gap even widens in 2008, although not significantly. In contrast, the deviation of the expected retirement age between high- and low-educated older workers decreases and is not significant anymore in 2008. The findings for education are partially reflected in those for occupational status. While in all three observed years, self-employed people have the highest expected retirement age and blue-collar workers are closing with white-collar workers and public servants. The $\mathrm{R}^{2}$ of the regressions are comparable to previous research on the prospective retirement age [43]. Results also remain stable when applying the Heckman test to control for a potential selection bias. 
Although it clearly shows (Table A1, lower section) that female, lower-educated and older respondents have a higher probability of not answering the question-because they have a lower employment rate-, this does not bias the results (Table A1, upper section).

Table 1. The Relation of Education and Expected Retirement Age.

\begin{tabular}{lccc}
\hline & $\mathbf{1 9 8 7}$ & $\mathbf{1 9 9 6}$ & $\mathbf{2 0 0 8}$ \\
\hline Education (Ref: ISCED 0-2) & & & \\
$\quad$ ISCED 3-4 & $0.19(0.24)$ & $-0.07(0.35)$ & $-0.32(0.47)$ \\
ISCED 5-6 & $1.35(0.29)^{* * *}$ & $0.71(39)^{*}$ & $0.28(0.48)$ \\
Women (Ref: Man) & $-1.03(0.22)^{* * *}$ & $-1.09(0.2)^{* * *}$ & $-0.61(0.18)^{* * *}$ \\
Partner (Ref: No Partner) & $-0.44(0.24)^{* *}$ & $-0.67(0.29)^{* * *}$ & $-0.78(0.25)^{* * *}$ \\
\hline Occupational Position (Ref: Blue-Collar) & & & \\
$\quad$ White-Collar & $0.31(0.22)^{* *}$ & $0.58(0.23)^{* *}$ & $0.01(0.24)$ \\
Public Servant & $0.35(0.34)$ & $-0.30(0.40)$ & $-0.31(0.36)$ \\
$\quad$ Self-Employed & $2.50(0.29)^{* * *}$ & $1.99(0.3)^{* * *}$ & $1.67(0.32)^{* * *}$ \\
Occupational Pension (Ref: No Occ.Pension) & $-0.68(0.34)^{* * *}$ & $-0.60(0.20)^{* * *}$ & $-0.45(0.19)^{* *}$ \\
Constant & $61.01(0.24)$ & $62.41(0.44)$ & $64.47(0.53)$ \\
Number of Observations & 638 & 767 & 1187 \\
$\mathrm{R}^{2}$ & 0.18 & 0.15 & 0.07 \\
\hline
\end{tabular}

${ }^{*}<0.1 ; * * 0.05 ;{ }^{* * *}<0.01$.

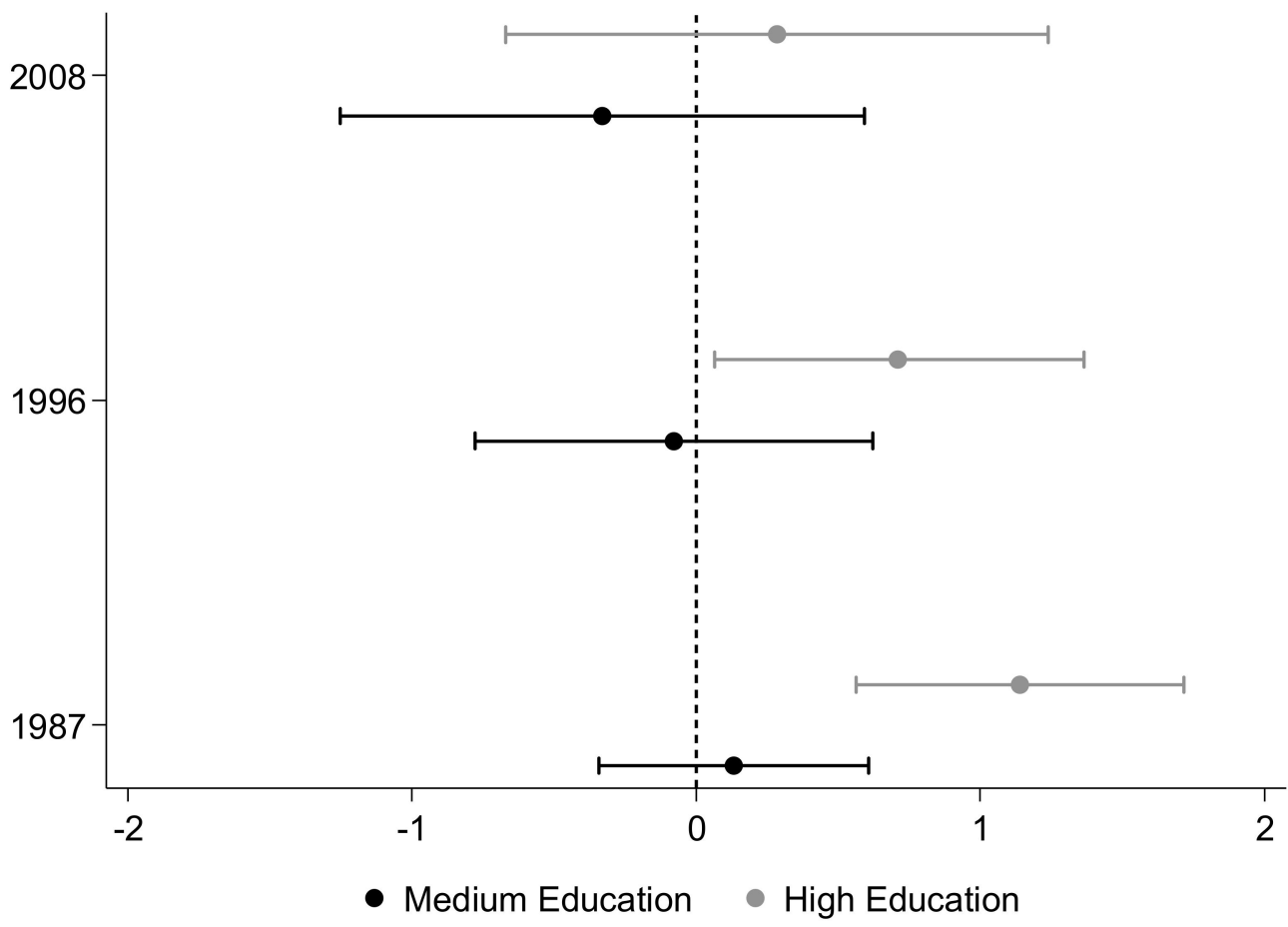

Figure 2. The Relation of Education and Expected Retirement Age * * Based on the regression in Table 1. Reference category is Low Education (ISCED 0-2). The relationship is statistically significant when the $90 \%$ confidence interval (gray and black vertical lines) does not overlap the dotted line.

\section{Discussion}

Germany's pensions system and the labor market have undergone many strong reforms in the last 20 years. Early retirement pathways were closed and the statutory retirement age was raised [12,26]. In addition, the German state implemented programs training older low-skilled workers and subsidized companies for employing older workers, while employers introduced human resource measures aimed at older workers [31,32]. As a result, the employment rate and average retirement 
age of older workers increased [12]. The reforms not only influenced the retirement behavior of today's retirees but also future pensioners' expectations of when to retire. In this paper, I investigated the development of the expected retirement age in Germany from 1987 to 2008 and complemented previous research by showing that the increase of the expected retirement age also takes place in Germany and that it is a longer-lasting development of the last 20 years instead of a rather recent phenomenon. A second contribution of the paper is that it supports recent concerns about rising social inequality in the retirement process.

The results show, as stated in Hypothesis 1, that the expected retirement age has increased between 1987 and 2008 for all educational groups; however, the increase was strongest for workers with low education. I also showed that the increase of the expected retirement age was strong particularly for low-skilled workers, supporting Hypothesis 2, as they were the main target group of the early retirement pathways and, when these were closed, had to adapt most to the new situation. This finding is also reflected in the strong increase of the expected retirement age of blue-collar workers, which again supports the findings on educational differences. To conclude, the results of this paper indicate that expected retirement ages have shifted and come closer into alignment between educational groups. The findings are in line with previous studies which show that (1) social inequality in the transition from work to retirement is increasing [18]. The blue-collar and low-educated workers used to have the possibility of early retirement with only little pension reduction and, thus, expected to retire early. Now they expect they have to work as long as their peers with better education, but in much harder working conditions and with often physically demanding labor. (2) The increase of the statutory retirement age seems to be more acceptable to those with high education [47] and (3) the share of low-skilled and low-educated older workers in Germany who have to work beyond the official retirement age to ensure a decent standard of living is increasing $[19,48]$.

Three main caveats have to be acknowledged when interpreting the study's results. First, the data is derived from two different studies; therefore, the questions on the expected retirement age differ slightly. However, only questions that have standardized answers (For example the ISCED) or that are identical were used for the regression's explanatory variables so that one can assume a high comparability across the datasets. Second, the explanatory power of the regression models is comparably low. This can be explained by the fact that the dependent variable is a subjective notion and not a hard fact, hence, correlations tend to be lower and the $\mathrm{R}^{2}$ is comparable to that of previous studies $[43,49]$. Still, it must be acknowledged when interpreting the results. Third, the analysis was limited to Germany and, thus, a comparison between countries was not possible. More countries should be included into the analysis to ensure a wider range of comparison of the excepted retirement ages and to examine how the different reforms vary in their impact. Finally, future research could investigate differences in the perception and evaluation of the increasing retirement ages. One could speculate that those with low education should be less satisfied than those with high education leading to difference in redistributive preferences with the low educated wanting more redistribution within the pension systems and the high educated preferring less. This dissatisfaction with the pension system might even cause frustration with the welfare state in general and the democratic system. Older, low educated workers might lean more towards extreme parties or even stop voting at all.

To conclude, these scientific findings also carry societal and political implications. As we have seen, the findings in this paper support the concerns of rising social inequality in the transition from work to retirement $[11,21]$. While the high-skilled employees with tertiary education not only expect but also desire to work longer [49], we find a different development for low-educated older workers. They seem to have adapted their expected retirement age because of financial needs and in order to ensure a reasonable pension $[19,48]$. While in the last century the early retirement pathways allowed them to withdraw early from the labor market with only low pension deductions, they now have to delay retirement and extend their employment in often unfavorable working conditions. Although the study at hand is based on German data, one could assume to find similar development in other countries. Policy makers, trade unions and employers therefore have to consider these developments 
when implementing further pension and labor market reforms in Germany and other countries facing demographic ageing and implementing reforms aimed at delaying retirement.

Funding: This research received no external funding.

Conflicts of Interest: The authors declare no conflict of interest.

\section{Appendix A}

Table A1. OLS Regression on the Expected Retirement Age with Heckman Test Control.

\begin{tabular}{lccc}
\hline & $\mathbf{1 9 8 7}$ & $\mathbf{1 9 9 6}$ & $\mathbf{2 0 0 8}$ \\
\hline Education (Ref: ISCED 0-2) & & & \\
$\quad$ ISCED 3-4 & $0.39(0.32)$ & $-0.13(0.37)$ & $-0.22(0.48)$ \\
ISCED 5-6 & $1.68(0.38)^{* *}$ & $0.66(0.41)^{\dagger}$ & $0.45(0.50)^{* *}$ \\
Women (Ref: Man) & $-1.60(0.30)^{* *}$ & $-1.08(0.22)^{* *}$ & $-0.68(0.19)^{* *}$ \\
Partner (Ref: No Partner) & $-0.41(0.25)$ & $-0.65(0.29)^{* *}$ & $-0.75(0.25)^{* *}$ \\
\hline Occupational Position (Ref: Blue-Collar) & & & \\
$\quad$ White-Collar & $0.33(0.23)^{*}$ & $0.57(0.23)^{\dagger}$ & $0.00(0.26)$ \\
$\quad$ Public Servant & $0.33(0.36)$ & $-0.30(0.40)$ & $-0.33(0.36)$ \\
$\quad$ Self-Employed & $2.45(0.35)^{* *}$ & $1.87(0.34)^{* *}$ & $1.55(0.32)^{* *}$ \\
Occupational Pension (Ref: No Occ.Pension) & $-0.48(0.39)$ & $-0.59(0.20)^{* *}$ & $-0.44(0.18)^{*}$ \\
Constant & $58.69(0.37)$ & $62.12(0.46)$ & $63.81(0.55)$ \\
Number of Observations & 612 & 767 & 1187 \\
\hline Selection coefficients & & & \\
\hline Education (Ref: ISCED 0-2) & & & $0.42(0.18)^{*}$ \\
ISCED 3-4 & & & $0.52(0.19)^{* *}$ \\
ISCED 5-6 & $0.27(0.15)^{* *}$ & $0.20(0.20)^{*}$ & $-0.14(0.09)^{\dagger}$ \\
Women (Ref: Man) & $0.57(0.18)^{* *}$ & $0.43(0.21)^{* *}$ & \\
\hline Age Groups (Ref: 50-55) & $-0.46(0.05)^{* *}$ & $-0.20(0.11)^{\dagger}$ & $-0.57(0.21)^{* *}$ \\
56-60 & & & $-0.78(0.29)^{* *}$ \\
61-65 & $-0.98(0.24)^{* *}$ & $-0.69(0.23)^{* *}$ & 0.55 \\
Rho & $-1.23(0.45)^{* *}$ & $-1.01(0.34)^{* *}$ & 3.14 \\
Sigma & 0.64 & 0.61 & 2.78 \\
\hline
\end{tabular}

${ }^{+}<0.1{ }^{*}<0.05 ;{ }^{* *}<0.01$.

\section{References}

1. German Federal Statistical Office. Bevölkerungs- und Haushaltsentwicklung im Bund und in den Ländern. In Demografischer Wandel in Deutschland, 1; Statistische Ämter des Bundes und der Länder: Wiesbaden, Germany, 2011.

2. De Tavernier, W.; Roots, A. When do people want to retire? The preferred retirement age gap between Eastern and Western Europe explained. Stud. Transit. States Soc. 2015, 7, 7-20.

3. Domonkos, S. Promoting a higher retirement age: A prospect-theoretical approach. Int. J. Soc. Welf. 2015, 24, 133-144. [CrossRef]

4. Harper, S. The Challenges of the Twenty-Frist-Century Demography. In Challenges of Aging: Retirement, Pensions, and Intergenerational Justice; Torp, C., Ed.; Palgrave Macmillan UK: Basingstoke, UK, 2015; pp. 17-30.

5. Naumann, E. Increasing conflict in times of retrenchment? Attitudes towards healthcare provision in Europe between 1996 and 2002. Int. J. Soc. Welf. 2014, 23, 276-286. [CrossRef]

6. Naumann, E. Do increasing reform pressures change welfare state attitudes? An experimental study on population ageing, pension reform preferences, political knowledge and ideology. Ageing Soc. 2015, 37, 266-294. [CrossRef]

7. Leve, V.; Naegele, G.; Sporket, M. Retirement at 67-Prerequisites for the ability of older female jobholders to continue working. Z. Gerontol. Geriatr. 2009, 42, 287-291. [CrossRef] [PubMed]

8. Frerichs, F.; Naegele, G. Active ageing in employment-Prospects and policy approaches in Germany. In Ageing Labour Forces. Promises and Prospects; Taylor, P., Ed.; Edward Elgar Publishing: Northampton, MA, USA, 2008; pp. 174-203. 
9. Moehring, K. Employment histories and pension incomes in Europe: A multilevel analysis of the role of institutional factors. Eur. Soc. 2015, 17, 3-26. [CrossRef]

10. Ebbinghaus, B.; Hofäcker, D. Overcoming Early Retirement in Europe. Comp. Popul. Stud. 2013, 38, 807-840.

11. Dietz, M.; Walwei, U. Germany-No country for old workers? Z. Arbeitsmarktforsch. 2011, 44, 363-376. [CrossRef]

12. Brussig, M. Changes in labour market participation of older employees in Germany. The perspective of labour market research. Z. Gerontol. Geriatr. 2009, 42, 281-286. [CrossRef] [PubMed]

13. Wong, J.D.; Hardy, M.A. Women's Retirement Expectations: How Stable Are They? J. Gerontol. B Psychol. Sci. Soc. Sci. 2013, 64, 77-86. [CrossRef] [PubMed]

14. Örestig, J.; Strandh, M.; Stattin, M. A Wish Come True? A Longitudinal Analysis of the Relationship between Retirement Preferences and the Timing of Retirement. J. Popul. Ageing 2013, 6, 99-118. [CrossRef]

15. Cobb-Clark, D.A.; Stillmann, S. The Retirement Expectations of Middle-aged Australians. Econ. Rec. 2009, 85, 146-163. [CrossRef]

16. Örestig, J.; Larsson, D.; Stattin, M. Retirement Preferences before and after Pension Reform: Evidence from Swedish Natural Experiment. 2013. Available online: http:/ / urn.kb.se/resolve?urn=urn:nbn:se:umu: diva-80804 (accessed on 6 February 2017).

17. De Grip, A.; Fouarge, D.; Montizaan, R.M. How Sensitive are Individual Retirement Expectations to Raising the Retirement Age? Economist 2013, 161, 225-251. [CrossRef]

18. Hofäcker, D.; Naumann, E. The emerging trend of work beyond retirement age in Germany. Z. Gerontol. Geriatr. 2015, 48, 473-479. [CrossRef] [PubMed]

19. Hochfellner, D.; Burkert, C. Employment in retirement. Continuation of a working career or essential additional income? Z. Gerontol. Geriatr. 2013, 46, 242-250. [CrossRef] [PubMed]

20. Buchholz, S.; Rinklake, A.; Blossfeld, H.P. Reversing Early Retirement in Germany. A Longitudinal Analysis of the Effects of Recent Pension Reforms on the Timing of the Transition to Retirement and on Pension Income. Comp. Popul. Stud. 2013, 38, 881-906.

21. Rinklake, A.; Buchholz, S. Increasing inequalities in Germany: Older people's employment lives and income conditions since the mid-1980s. In Ageing Populations, Globalization and the Labour Market. Comparing Late Working Life and Retirement in Modern Societies; Blossfeld, H.-P., Buchholz, S., Kurz, K., Eds.; Edward Elgar Publishing: Cheltenham, UK, 2011; pp. 35-64.

22. Ebbinghaus, B. Reforming Early Retirement in Europe, Japan and the USA; Oxford University Press: Oxford, UK, 2008.

23. Radl, J. Retirement Timing and Social Stratification. In A Comparative Study of Labor Market Exit and Age Norms in Western Europe; De Gruyter Open: Berlin, Germany, 2014.

24. Bönke, T.; Schröder, C.; Schulte, K. Income and Inequality in the Long Run: The Case of German Elderly. Ger. Econ. Rev. 2009, 11, 487-510. [CrossRef]

25. Naegele, G. Older workers and older worker policies in Germany. In Older Workers in an Ageing Society: Critical Topics in Research and Policy; Taylor, P., Ed.; Edward Elgar Publishing: Cheltenham, UK, 2014; pp. 39-61.

26. Buchholz, S. Men's late careers and career exits in West Germany. In Globalization, Uncertainty and Late Careers in Society; Blossfeld, H.-P., Buchholz, S., Hofäcker, D., Eds.; Routledge: Abingdon, UK, 2006; pp. 55-77.

27. Hofäcker, D.; Neumann, I.; Hess, M. Generationenpolitiken für "Junge" und "Alte". Neue Z. Familienr. 2015, 23, 1108-1110.

28. Rürup, B. The German Pension System: Status Quo and Reform Options; University of Chicago Press: Chicago, IL, USA, 2002.

29. Corneo, C.; Schröder, C. Bewertung der Riester-Rente: Volkswirtschaftliche Kriterien und Anforderungen an die Daten. Z. Sozial. 2012, 2, 235-257.

30. Duell, N.; Vogler-Ludwig, K. European Employment Observatory EEO Review: Employment Policies to Promote Active Ageing, Germany. 2012. Available online: http://www.economix.org/pdf/EEO\% 20Review\%20Germany-Older\%20Workers.pdf (accessed on 26 April 2017).

31. Naegele, G.; Walker, A. Age management in organizations in the European Union. In The SAGE handbook of Workplace Learning; Malloch, M., Cairns, L., Evans, K., O'Connor, B., Eds.; SAGE: London, UK, 2011; pp. 251-268. 
32. Naegele, G.; Sporket, M. Altern in der Arbeitswelt. Z. Gerontol. Geriatr. 2009, 42, 279-280. [CrossRef] [PubMed]

33. Hofäcker, D. In line or at odds with active ageing policies? Exploring patterns of retirement preferences in Europe. Aging Soc. 2015, 35, 1529-1556. [CrossRef]

34. Zappalà, S.; Depolo, M.; Fraccaroli, F.; Guglielmi, D.; Sarchielli, G. Postponing job retirement? Psychosocial influences on the preference for early or late retirement. Career Dev. Int. 2008, 13, 150-167. [CrossRef]

35. Esser, I. Continued Work or Retirement; Institute for Future Studies: Stockholm, Sweden, 2005.

36. Szinovacz, M.E.; Martin, L.; Davey, A. Recession and Expected Retirement Age: Another Look at the Evidence. Gerontologist 2014, 54, 245-257. [CrossRef] [PubMed]

37. Sargent-Cox, K.A.; Anstey, K.J.; Kendig, H.; Skladzien, E. Determinants of Retirement Timing Expectations in the United States and Australia: A Cross-National Comparison of the Effects of Health and Retirement Benefit Policies on Retirement Timing Decision. J. Aging Soc. Policy 2012, 24, 291-308. [CrossRef] [PubMed]

38. Wagner, G.G.; Frick, J.R.; Schupp, J. The German Socio-Economic Panel Study (SOEP)—Scope, Evolution and Enhancements. Schmollers Jahrb. 2007, 127, 161-191. [CrossRef]

39. Motel-Klingbiel, A.; Wurm, S.; Tesch-Römer, C. Altern im Wandel. Befunde des Deutschen Alterssurveys (DEAS); Kohlhammer: Stuttgart, Germany, 2010.

40. Ekerdt, D.J.; Rose, C.L.; Bosse, R.; Costa, P.T. Longitudinal change in preferred age of retirement. J. Occup. Psychol. 1976, 49, 161-169. [CrossRef]

41. Micheel, F.; Roloff, J.; Wickenheiser, I. Die Bereitschaft zur Weiterbeschäftigung im Ruhestandsalter im Zusammenhang mit sozioökonomischen Merkmalen. Comp. Popul. Stud. 2010, 35, 833-868.

42. Heckman, J.J. Sample Selection Bias as a Specification Error. Econometrica 1979, 47, 153-161. [CrossRef]

43. Hofäcker, D.; Hess, M.; Naumann, E. Changing retirement transitions in times of paradigmatic political change: Towards growing inequalities? In Challenges of Aging: Retirement, Pensions, and Intergenerational Justice; Torp, C., Ed.; Palgrave Macmillan UK: Basingstoke, UK, 2015; pp. 205-226.

44. Honig, M. Retirement Expectations: Differences by Race, Ethnicity, and Gender. Gerontologist 1996, 36, 373-382. [CrossRef] [PubMed]

45. Radl, J. Labour Market Exit and Social Stratification in Western Europe: The Effects of Social Class and Gender on the Timing of Retirement. Eur. Soc. Rev. 2013, 29, 654-668. [CrossRef]

46. Schils, T. Early Retirement in Germany, the Netherlands, and the United Kingdom: A Longitudinal Analysis of Individual Factors and Institutional Regimes. Eur. Soc. Rev. 2008, 24, 315-329. [CrossRef]

47. Naumann, E. Raising the retirement age: Retrenchment, feedback and attitudes. In How Welfare States Shape the Democratic Public: Policy Feedback, Participation, Voting and Attitudes; Kumlin, S., Stadelmann-Steffen, I., Eds.; Edward Elgar Publishing: Cheltenham, UK, 2014; pp. 223-243.

48. Scherger, S. Zwischen Privileg und Bürde. Erwerbstätigkeit jenseits der Rentengrenze in Deutschland und Großbritannien. Z. Sozial. 2013, 59, 137-166. [CrossRef]

49. Hess, M. Expected and Preferred Retirement Age in Germany. Z. Gerontol. Geriatr. 2018, 51, 98-104. [CrossRef] [PubMed]

(c) 2018 by the author. Licensee MDPI, Basel, Switzerland. This article is an open access article distributed under the terms and conditions of the Creative Commons Attribution (CC BY) license (http:// creativecommons.org/licenses/by/4.0/). 